Scientific article

Volumen 33(2): Artículo 46404, 2022

e-ISSN 2215-3608, doi:10.15517/am.v33i2.46404

https://revistas.ucr.ac.cr/index.php/agromeso/index

\title{
Effect of induction moment on Bradyrhizobium-soybean (Glycine max) interaction $^{1}$
}

\section{Efecto del momento de inducción en la interacción Bradyrhizobium-soya (Glycine max)}

\author{
María Caridad Nápoles-García ${ }^{2}$, Daimy Costales-Menéndez $z^{2}$, Ionel Hernández-Forte², Reneé Pérez-Pérez², \\ Guilleaume Wegria ${ }^{3}$, Juan Carlos Cabrera-Pino ${ }^{3}$
}

1 Reception: March $26^{\text {th }}, 2021$. Acceptance: September $14^{\text {th }}, 2021$. This work was part of a colaborative project between the Instituto Nacional de Ciencias Agricolas, Rizobacter S.A. Company, and Fyteko S.A. Company.

2 Instituto Nacional de Ciencias Agricolas (INCA), Plant Physiology and Biochemistry Department. San José de las Lajas. Mayabeque, Cuba. PC 32700. tere@inca.edu.cu (Corresponding author; http://orcid.org/0000-0003-1413-1717); daimy@inca.edu.cu (http://orcid.org/00000003-0121-6287); ionel@inca.edu.cu (http://orcid.org/0000-0002-5760-816X), riny@inca.edu.cu (http://orcid.org/0000-0002-5144-212X).

3 Fyteko S.A. Company. Allée de la Recherche 4, 1070 Anderlecht, Belgium. jcc@ fyteko.com (http://orcid.org/0000-0001-8321-1070); gw@ fyteko.com (https://orcid.org/0000-0001-8468-7919).

\begin{abstract}
Introduction. Legume nodulation is regulated by the exchange of molecular signals between the plant and rhizobia. The bacterial nodulation genes are activated by flavonoids present in root exudates. As a result of this activation, the Nod factors are synthesized, which in turn participate in the morphogenesis and function of the nodules. It is then possible to regulate the induction of Nod factors and other signals related to the nodulation process, during the inoculants production. Objective. To determine if the moment to induce the nodulation genes in Bradyrhizobium inoculants affects the synthesis of compounds related to the nodulation process and its interaction with soybean plants. Materials and methods. The research was developed in Rizobacter S.A., Argentina and Fyteko S.A. laboratories, Belgium, and in a plant growth chamber of the first one, during May-June of 2017. Two Bradyrhizobium strains were induced with daidzein in three moments. The signals produced by the strains and the biological effect in soybean plants were studied. Results. Differences were detected in the molecules produced by the bacteria, but it did not affect the growing and plants nodulation related to the different moments of induction. Conclusion. The metabolites excreted by Bradyrhizobium changed with strain and induction moment, although the latter did not affect nodulation or soybean plants growth.
\end{abstract}

Keywords: symbiosis, signals, time, response.

\section{Resumen}

Introducción. La nodulación en leguminosas está regulada por el intercambio de señales moleculares entre la planta y los rizobios. Los genes de nodulación de la bacteria son activados por flavonoides presentes en los exudados de las raíces. Como resultado de esa activación se sintetizan los factores Nod, que a su vez participan en la morfogénesis y función de los nódulos. Es posible regular entonces, la inducción de factores Nod y de otras señales 
relacionadas con el proceso de nodulación, durante la producción de inoculantes. Objetivo. Determinar si el momento de inducir los genes de nodulación en inoculantes de Bradyrhizobium afecta la síntesis de compuestos relacionados con el proceso de nodulación y su interacción con plantas de soya. Materiales y métodos. La investigación se desarrolló en los laboratorios de dos empresas: Rizobacter S.A., Argentina y Fyteko S.A., Bélgica, así como en una cámara de crecimiento de plantas de la primera empresa, durante mayo y junio del año 2017. Dos cepas de Bradyrhizobium fueron inducidas con daidzeína en tres momentos. Se estudiaron las señales producidas por las cepas y el efecto biológico en las plantas de soya. Resultados. Se detectaron diferencias en las moléculas producidas por las bacterias, pero no en el crecimiento y la nodulación de las plantas, relacionado con los diferentes momentos de inducción. Conclusión. Los metabolitos excretados por Bradyrhizobium variaron con la cepa y el momento de la inducción, aunque este último no afectó la nodulación ni el crecimiento de las plantas de soya.

Palabras clave: simbiosis, señales, tiempo, respuesta.

\section{Introduction}

Gram-negative soil bacteria Bradyrhizobium spp. infects and establishes a nitrogen-fixing symbiosis with soybean, which involves the mutual exchange of diffusible signal molecules, resulting in root nodule formation (Ramongolalaina et al., 2018). The initial steps of this symbiotic interaction involve reciprocal communication by means of chemical signals produced by both members of the symbiosis. This process is triggered by the interaction between flavonoid compounds from root exudates and the protein product of the regulatory nodD gene of the bacterium (Naveed et al., 2015).

Several nod gene inducers from leguminous root exudates have been identified as isoflavone and flavanone molecules and their results is Nod factor production (Gautam et al., 2016). The isoflavonoids genistein and daidzein have been shown to be the primary inducers of nod gene expression in Bradyrhizobium japonicum (Kosslak et al., 1987). Nod factors are lipochitinoligosaccharides (LCO), which results in a wide transcriptional reprogramming that leads to coordinated multistep processes of infection and nodule organogenesis, involving many plant and bacterial molecular components (Mbengue et al., 2020).

The use of rizobia inoculants in legume seeds is maybe the oldest agrobiotechnological application. The inoculation of soybean with Bradyrhizobium spp. can fully supply the crop's demand on N (Hungria \& Mendes, 2015). Several works have demonstrated positive effects on soybean growth, nodulation and yield of inoculants based on Bradyrhizobium (Jarecki, 2020; Leggett et al., 2017; Secchi et al., 2019).

Secondary metabolites produce by rhizobia may provide an evolutionary advantage for survival of microbes in soil (Demain, 1998), they also help in the establishment of symbiotic partnerships (Brencic \& Winans, 2005), and added quality to the inoculants in their effect on plants (Nápoles et al., 2016). The use of secondary metabolites of rhizobia indicates biotechnological potential to improve growth and grain yields of crops as soybean and maize (Marks et al., 2013).

Great efforts have been applied by several industries to develop new products able to attend the new requirements of the market. The tendency is to apply considerable investment in innovation, searching for new inoculant formulations to hit the ever growing market (Santos et al., 2019). The manipulation of fermentation conditions is among the suggested tools for enhancing the chances of commercial scale production and thus the field applications of these bioproducts.

The induction of LCOs or Nod factors secreted by rhizobia is between the priorities of research on improved delivery systems. Potential commercial LCO products for seed and foliar applications in legumes and nonlegumes, 
such as corn, are currently available in the marketplace. More exploration in this direction is required to get more benefits from plant growth promotion bacteria (Bashan et al., 2014).

Preliminary studies, have demonstrated the differentiated nod genes induction in time, pointing to the $\log$ phase. The expression of the nodD gene per cell appears to increase substantially in the early log phase to Rhizobium trifolii- induced with flavones from clover (Djordjevic et al., 1987). In Rhizobium leguminosarum associated to Pisum sativum and Lens culinaris, one study refer the best inducing time with naringenin and hesperitin at $7 \mathrm{~h}$ after culturing cells and the maximal inductions were obtained at $24 \mathrm{~h}$ after induction (Begum et al., 2001).

The objective of this study was to determine if the moment to induce the nodulation genes in Bradyrhizobium inoculants affects the synthesis of compounds related to the nodulation process and their interaction with soybean plants.

\section{Materials and methods}

The research was developed in the company Rizobacter S.A., Argentina and in the laboratories of Fyteko S.A., Belgium, in May-June of 2017.

\section{Bacterial strains and growth conditions}

Bradyrhizobium japonicum SEMIA 5079 was obtained from the FEPAGRO (Fundação Estadual de Pesquisa Agropecuária) culture collection. The strain was selected because it is widely used in commercial B. japonicum inoculants in Brazil and Argentina (Hungria et al., 2006). Other Bradyrhizobium sp. strain (537), isolated from Argentinian soils, was used to compare. The cultures were grown at $28{ }^{\circ} \mathrm{C}$ in $100 \mathrm{~mL}$ of yeast mannitol medium (Vincent, 1970).

\section{Induction experiment}

To induce Nod factor (nodulation factors) and other molecules related with nodulation synthesis, the medium was supplemented by the addition of $10 \mu \mathrm{M}$ daidzein (Sigma) at three moments: since the beginnings (time zero), at 32 hours (when bacteria were in exponential phase) and finally when inoculants were formulated. A not induced culture was used as control (NI). Flasks induced or not were shaken at $150 \mathrm{rpm}$ for 60 hours on an incubator orbital shaker. Bacterial cultures $\left(1.4-1.8 \times 10^{9} \mathrm{CFU} \mathrm{ml}^{-1}\right)$ were used to inoculate soybean seeds at rate of $25 \mathrm{~mL} 100 \mathrm{~g}^{-1}$ seed.

\section{Extraction of the lipidic fraction}

Taking into account that the majority of the signals recognized for their biological activity in the rhizobialeguminous interaction are lipid, a selective extraction of these molecules from the inoculum treated with daidzein (Induced) or not (Control) was performed, using $180 \mathrm{~mL}$ of n-butanol in each sample. They were put in orbital shaker at $150 \mathrm{rpm}$ for $15 \mathrm{~min}$ and kept resting overnight at dark and room temperature of $25 \pm 2{ }^{\circ} \mathrm{C}$. The organic phase was then extracted in each sample, centrifuged at $12000 \mathrm{~g}, 10^{\circ} \mathrm{C}$, for $10 \mathrm{~min}$. All samples were concentrated by rotoevaporation at $50-80{ }^{\circ} \mathrm{C}$ until $2 \mathrm{~mL}$ of each was obtained, which were used for the detection of signals produced by the bacteria. 


\section{Metabolite detection in the lipidic fraction by gas chromatography-mass spectrometry (GC-MS)}

Volatile derivatives of extracted metabolites were prepared by silylation, using BSTFA (N, O-Bis (trimethylsilyl) trifluoroacetamide) as reagent in combination with trimethyl chlorosilane (TMCS) (Kit BSTFA + TMCS, Supelco).

For analysis by GC-MS, a gas chromatograph coupled to a Shimadzu GC-MS QP-2010 mass spectrometer was used; system equipped with AOC-20i auto-injector, AOC-20s autosampler and a direct insertion system controlled by the GC-MS solution software. An Optima 5 MS column ( $30 \mathrm{~m} \times 0.25 \mathrm{~mm}$ ID, $0.25 \mu \mathrm{m}$ film thickness) was used.

The conditions of the chromatographic analyzes were: injector temperature $310{ }^{\circ} \mathrm{C}$, oven temperature 100 ${ }^{\circ} \mathrm{C}$ during $6 \mathrm{~min}$. It was subsequently increased to $320{ }^{\circ} \mathrm{C}$ at a rate of $20{ }^{\circ} \mathrm{C} \mathrm{min}-1$ and maintained for $5 \mathrm{~min}$. The injection volume was $1 \mu \mathrm{L}$ and the flow in the column of $0.75 \mathrm{~mL} / \mathrm{min}$, using helium as entrainment gas. All the detected signals were normalized and relative values expressed in function of the retention time (min).

\section{Plant growth conditions}

Soybean seeds cv. DM 4600 RR were inoculated with the different treatments. Non-inoculated seeds were used as control. A soil in which soybean had not been grown was used for the assay. Plants were cultivated in a growth chamber with 5000 lux of illumination, temperature of $25-30{ }^{\circ} \mathrm{C}$ and $60-70 \%$ of relative humidity for 31 days. Plants were harvested at stage V3 (35 days after sowing); corresponding to the vegetative stage with at least three fully developed trifoliate leaves. The number and dry matter of nodules on main and total root were determined. Also shoot and root dry mass, were evaluated.

\section{Experimental design and statistical analysis}

The experiments were conducted twice. Results from the second assay are shown. Treatments were a completely randomized design with factorial arrangements composed by 2 strains x 3 moments +2 references witness, with a total of eight treatments. Also, the control without inoculation and both strains non induced were compared. Ten replicates were used in every treatment. The Info-Stat program was used for two-ways analysis of variance. Where a significant treatment effect $(\mathrm{p}<0.05)$ was observed by ANOVA, Multiple ranges of Tukey HSD test was conducted to determine differences among means at $\mathrm{p}<0.05$.

\section{Results}

A representative normalized chromatogram to analyse the diversity of metabolites produced by Bradyrhizobium sp. 537 and B. japonicum 5079 without induction (NI) or induced with daidzein at time zero (0h), in exponential phase (32 h) and in the formulated (Form), is shown in Figure 1 and 2, and indicates the different metabolites profiles among the two strains.

In the gas chromatography column used, low molecular weight metabolites (sugars, amino acids) elute early (low retention time values) from the column, while higher molecular weight metabolites (fatty acids, oligosaccharides) elute late (high retention time values). In the non-induced culture medium, strain 537 produced a broader diversity and higher content of metabolites than strain 5079. Additionally, the two studied strains also reacted differently at the time of application of the Nod fact inductor.

The most significant change in the metabolite profile in the strain 537 was observed when the inducer was added at $32 \mathrm{~h}$, showing significantly higher content values for almost all the metabolites detected. However, strain 


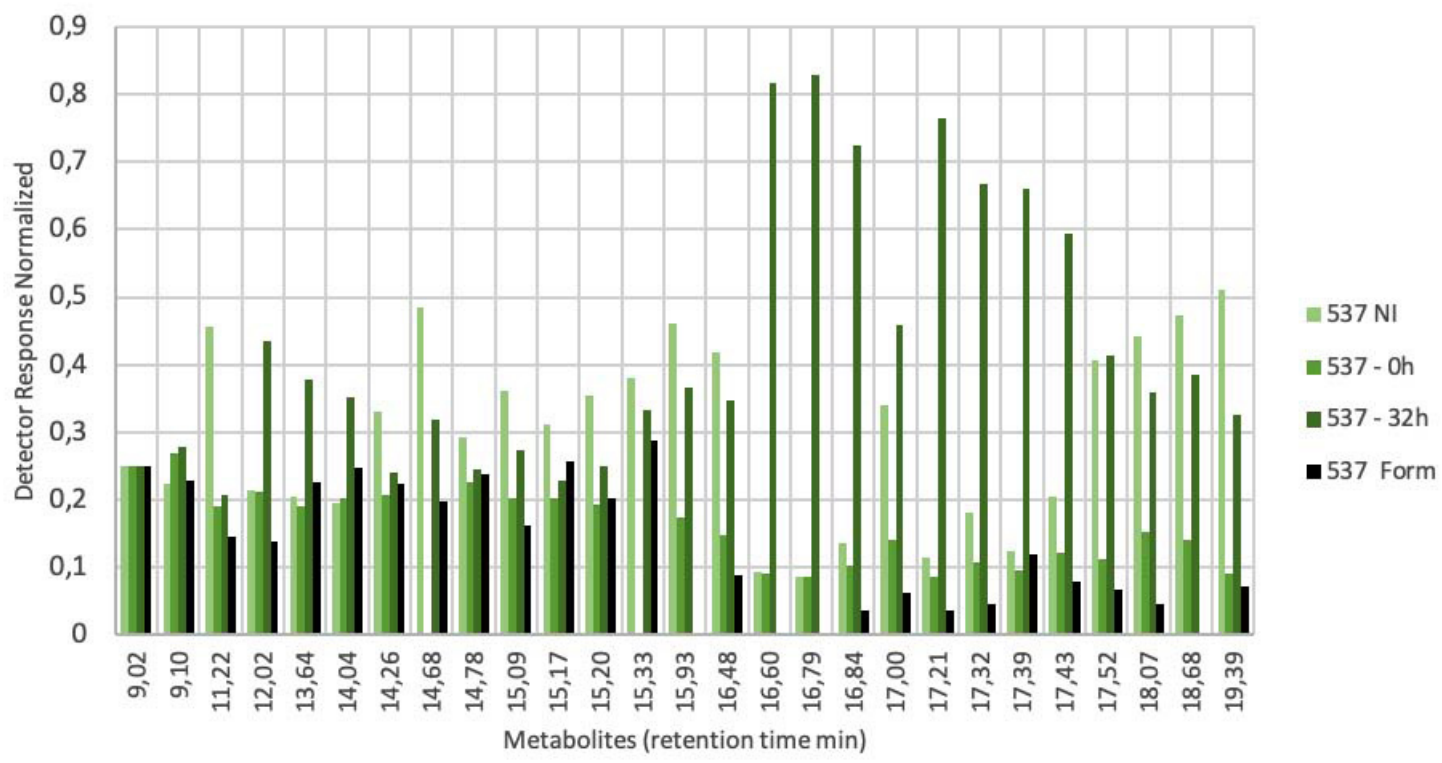

Figure 1. Gas chromatography-mass spectrometry (GC-MS) profile of metabolites extracted from strain Bradyrhizobium sp. 537 without inducing (NI) or induced with daidzein at time zero $(0 \mathrm{~h})$, in the exponential phase $(32 \mathrm{~h})$ and in the formulated (Form). Fyteko S.A., Brussels, Belgium, 2017.

Figura 1. Perfil de metabolitos en cromatografía gaseosa-espectrometría de masas (CG-EM) extraídos de la cepa Bradyrhizobium sp. 537 sin inducir (NI) o inducida con daidzeína a tiempo cero (0 h), en la fase exponencial (32 h) y en el formulado (Form). Fyteko S.A., Bruselas, Bélgica, 2017.

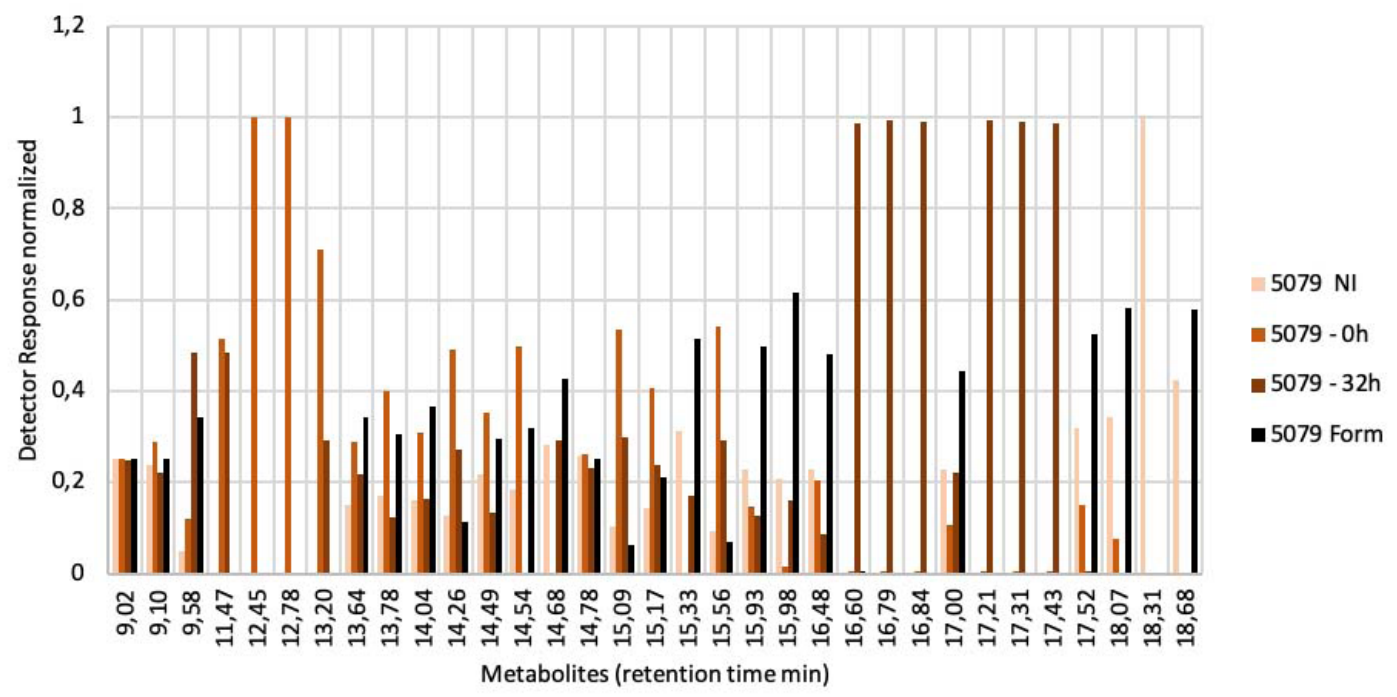

Figure 2. Gas chromatography-mass spectrometry (GC-MS) profile of metabolite extracted from the strain Bradyrhizobium japonicum 5079 without inducing (NI) or induced with daidzein at time zero $(0 \mathrm{~h})$, in the exponential phase (32 h) and in the formulated (Form). Fyteko S.A., Brussels, Belgium, 2017.

Figura 2. Perfil de metabolitos en cromatografía gaseosa-espectrometría de masas (CG-EM) extraídos de la cepa Bradyrhizobium japonicum 5079 sin inducir (NI) o inducida con daidzeína a tiempo cero ( 0 h), en la fase exponencial (32 h) y en el formulado (Form). Fyteko S.A., Bruselas, Bélgica, 2017. 
5079 showed a completely different response profile. In this last strain, significant changes were observed when the inducer was added at $0 \mathrm{~h}$, mainly in the content of low molecular weight metabolites. When the inducer was added at $32 \mathrm{~h}$, the greatest increase in content was observed for the high molecular weight metabolites. In both strains, adding the inducer in the formulation step does not seem to induce changes in the content and profile of metabolites.

The analysis in plants evidenced a positive effect of inoculation without induction (Figure 3). In all variables studied, plants inoculated with both strains show higher results than those non inoculated (Control), except in root dry weight, where non significative differences were found between control and strain 537 . The behavior between both strains was similar in all determinations.
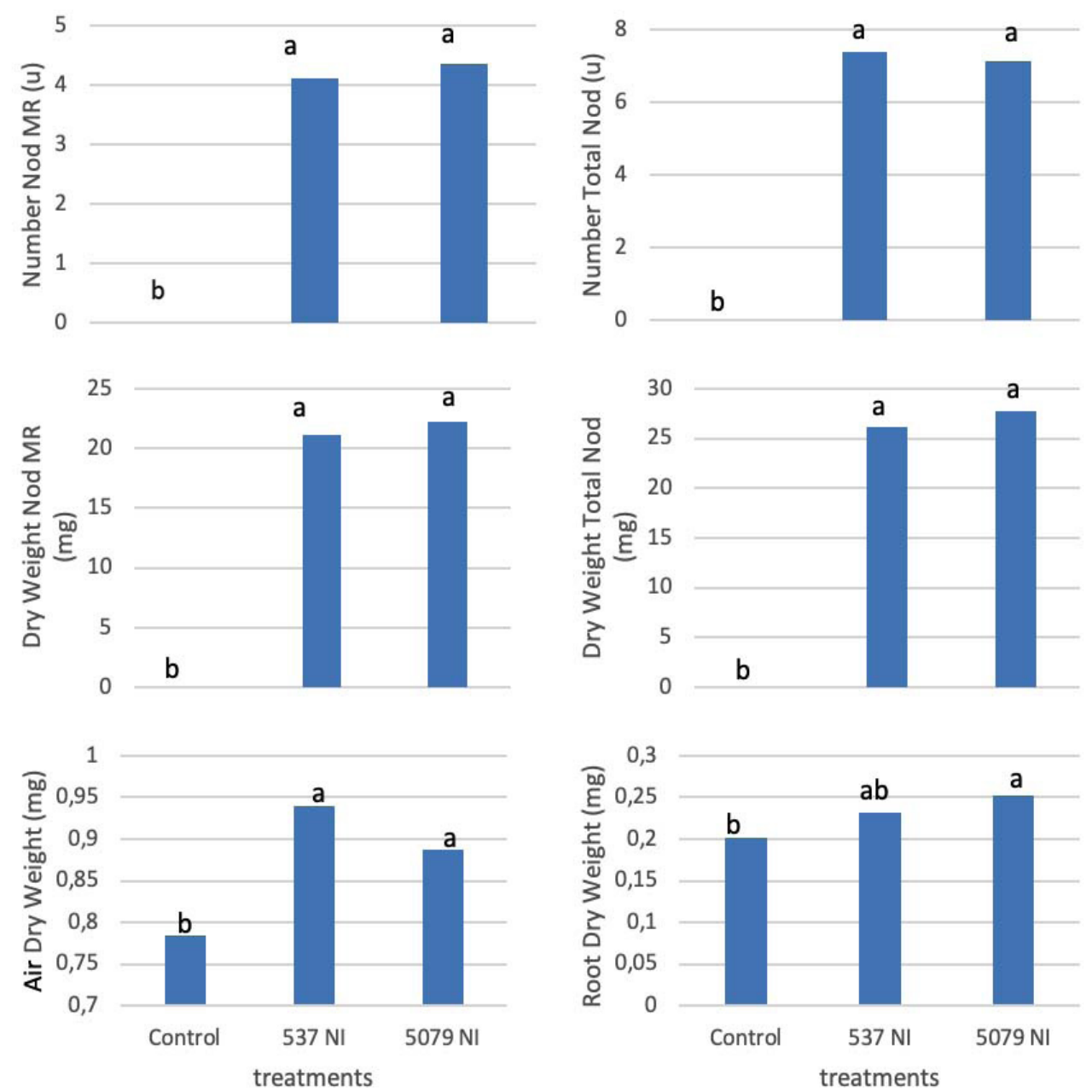

Figure 3. Effect of two Bradyrhizobium strains with non-induced culture (537 NI and 5079 NI) on the soybean (Glycine max) nodulation and growth, at 35 days, under controlled conditions. Pergamino, Argentina, 2017.

Means with equal letters do not differ statistically (ANOVA, $\mathrm{p} \leq 0.05$ ). Ten replicates were used in each treatment. Control (noninoculated plants), NI (plants treated with non-induced inoculum), Nod MR (nodules in main root), Total Nod (Total Nodules).

Figura 3. Efecto de dos cepas de Bradyrhizobium con cultivo no inducido (537 NI y 5079 NI) en la nodulación y crecimiento de soya (Glycine max), a los 35 días, bajo condiciones controladas. Pergamino, Argentina, 2017.

Medias con letras iguales no difieren estadísticamente (ANOVA, $\mathrm{p} \leq 0,05$ ). Se utilizaron diez réplicas en cada tratamiento. Control (plantas no inoculadas), NI (plantas tratadas con inóculo no inducido), Nod MR (nódulos en raíz principal), Total Nod (nódulos totales). 
The analysis showed interaction between factors strain and moment, and demonstrated in general, a positive response to induction, but no important differences related to the induction moments (Table 1).

Table 1. Effect of Bradyrhizobium inoculants induced at different times, on the growth of soybean (Glycine max) plants, at 35 days, under controlled conditions. Pergamino, Argentina, 2017.

Cuadro 1. Efecto de inoculantes de Bradyrhizobium inducidos en diferentes momentos, sobre el crecimiento de plantas de soya (Glycine max), a los 35 días, bajo condiciones controladas. Pergamino, Argentina, 2017.

\begin{tabular}{lcccccc}
\hline Strain/Moment & $\begin{array}{c}\text { Nodules main } \\
\text { root }(\mathbf{u})\end{array}$ & $\begin{array}{c}\text { Total nodules } \\
(\mathbf{u})\end{array}$ & $\begin{array}{c}\text { Dry weight } \\
\text { nodules main } \\
\text { root }(\mathbf{m g})\end{array}$ & $\begin{array}{c}\text { Dry weight } \\
\text { total nodules } \\
(\mathbf{m g})\end{array}$ & $\begin{array}{c}\text { Shoot dry } \\
\text { weight }(\mathbf{g})\end{array}$ & $\begin{array}{c}\text { Root dry } \\
\text { weight }(\mathbf{g})\end{array}$ \\
\hline $\mathbf{5 3 7 - N I}$ & 4.12 & 7.37 & 21.12 & 26.12 & 0.939 & 0.238 \\
$\mathbf{5 0 7 9 - N I}$ & 4.37 & 7.12 & 22.25 & 27.75 & 0.888 & 0.252 \\
$\mathbf{5 3 7 - 0 h}$ & $4.37 \mathrm{c}$ & $7.50 \mathrm{c}$ & $23.12 \mathrm{~b}$ & $34.75 \mathrm{abc}$ & $1.140 \mathrm{a}$ & $0.322 \mathrm{a}$ \\
$\mathbf{5 3 7 - 3 2 h}$ & $4.87 \mathrm{bc}$ & $11.25 \mathrm{ab}$ & $23.25 \mathrm{~b}$ & $35.87 \mathrm{ab}$ & $1.130 \mathrm{a}$ & $0.282 \mathrm{bc}$ \\
$\mathbf{5 3 7 - F o r m}$ & $4.50 \mathrm{bc}$ & $11.12 \mathrm{ab}$ & $22.87 \mathrm{~b}$ & $33.12 \mathrm{bc}$ & $1.110 \mathrm{ab}$ & $0.311 \mathrm{ab}$ \\
$\mathbf{5 0 7 9 - 0 h}$ & $7.75 \mathrm{a}$ & $12.50 \mathrm{a}$ & $29.75 \mathrm{a}$ & $38.50 \mathrm{a}$ & $1.110 \mathrm{ab}$ & $0.336 \mathrm{a}$ \\
$\mathbf{5 0 7 9 - 3 2 h}$ & $7.12 \mathrm{a}$ & $10.50 \mathrm{~b}$ & $26.77 \mathrm{ab}$ & $31.12 \mathrm{c}$ & $1.004 \mathrm{c}$ & $0.276 \mathrm{c}$ \\
$\mathbf{5 0 7 9 - F o r m}$ & $6.50 \mathrm{ab}$ & $11.50 \mathrm{ab}$ & $26.75 \mathrm{ab}$ & $37.75 \mathrm{a}$ & $1.038 \mathrm{bc}$ & $0.286 \mathrm{bc}$ \\
$\mathbf{E S x}$ & 0.48 & 0.48 & 0.94 & 1.06 & 0.02 & 0.007 \\
\hline
\end{tabular}

Means with equal letters do not differ statistically for $\mathrm{p}<0.05$, according to the Tukey HSD Multiple Range Test. / Medias con letras iguales no difieren estadísticamente para $\mathrm{p}<0,05$, según test de Tukey HSD prueba de rangos múltiples.

Legend: NI (non-induced culture), $0 \mathrm{~h}$ (inoculum induced from the beginnings), $32 \mathrm{~h}$ (inoculum induced in the log phase), Form (inoculum induced in the formulation). / Leyenda: NI (cultivo no inducido), $0 \mathrm{~h}$ (inóculo inducido desde el inicio), $32 \mathrm{~h}$ (inóculo inducido en la fase log), Form (inóculo inducido en el formulado).

The non-induced strains showed the lowest nodulation and growth values, with statistical differences in almost all the variables and with almost all the treatments, according to the ANOVA carried out, which shows the positive effect of induction in the inoculant.

In the number of nodules in the main root, the strain 5079 stood out, with increments from $48.74 \%$ up to 77 , $34 \%$, regarding the not induced strain. This strain also surpassed Bradyrhizobium sp. 537 in the first two induction moments, although there were no differences between the moments for any of the strains. However, in the number of total nodules, there was a similar behavior between the strains and the moments, there were only differences in favor of the 5079 strain for the $0 \mathrm{~h}$ induction, with $75.6 \%$ increment, regarding the not induced strain; surpassing at the same induction time the other strain and itself when was induced at $32 \mathrm{~h}$.

In the dry mass of the nodules formed in the main root, there were only differences between the strains for the zero time of induction, in favor of 5079 and there were no differences between the moments for any of the strains. Compared to non-induced treatments both strain in every moment showed higher results. In the dry mass of total nodules, the 537-strain surpassed 5079 in the induction at $32 \mathrm{~h}$, but the contrary effect was found when they were induced at the formulation moment.

Considering the time of induction, there were only differences, with lower results when 5079 strain was induced at $32 \mathrm{~h}$. The results were positive when the cultures were induced, with differences between $26.8-37.3 \%$ to 537 strain and $12.1-38.7 \%$ to 5079 . 
Regarding the growth variables, in the shoot dry weight, there was a better behavior of strain 537 over 5079 when they were induced at $32 \mathrm{~h}$ and within each strain there were only differences for 5079 when moments 0 and $32 \mathrm{~h}$ were compared, in favor of the first moment. All inducing treatments overpassed the non-induced ones, with differences since 19.3 to $25.0 \%$.

In the root dry weight there were no differences between the strains. Between the moments, the 537 strain had a better performance at $0 \mathrm{~h}$ with respect to the induction at $32 \mathrm{~h}$, overpassing in $35.3 \%$ the non-induced treatment. Bradyrhizobium japonicum 5079 strain induced since the beginning of the multiplication, surpassed the remaining moments and the non-induced treatment with $33.33 \%$.

\section{Discussion}

In spite of both studied strains belong to the same genus, their produced metabolites profile was different. Similar results were found with diverse exo-metabolomic profile in distinct strains belonging to the same family (Rhizobiaceae) and all forming nitrogen-fixing nodules on Phaseolus vulgaris roots (Ramírez-Puebla et al., 2019).

In general, the effect of strain 5079 induced at $0 \mathrm{~h}$ stands out in all variables, although it did not differ from its induction in the formulated. There was no correspondence between the profile of metabolites excreted by these strains and their behavior in nodulation and growth in plants. Apparently, the moment to induce the nodulation genes in these Bradyrhizobium strains affected the synthesis of compounds, but not their interaction with soybean plants.

Preliminary studies, however, have demonstrated the differentiated nod genes induction in time, pointing to the log phase. The expression of the nodD gene per cell appears to increase substantially in the early log phase to Rhizobium trifolii- induced with flavones from Clover (Djordjevic et al., 1987). In Rhizobium leguminosarum associated to Pisum sativum and Lens culinaris, one study refer the best inducing time with naringenin and hesperitin at $7 \mathrm{~h}$ after culturing cells and the maximal inductions were obtained at $24 \mathrm{~h}$ after induction (Begum et al., 2001).

According to these results, in the production of Bradyrhizobium inoculants there were no great differences if the culture is induced from the beginning, at $32 \mathrm{~h}$, when it was in the exponential phase of growth, or in the final stage, during product formulation. This may be because in each of these stages the bacterium continues to multiply and induce because they were in contact with fresh nutrients from the culture medium and also with the inducer. Therefore, the cells continue dividing and accumulating LCOs and other metabolites as a result of induction. This finding could be interesting to produce soybean induced inoculants, taking into account that the moment to add the inducer is not restricted.

\section{Conclusions}

The excreted metabolites profile by Bradyrhizobium depended on the strain and the moment of induction.

The induction of Bradyrhizobium modulated the synthesis of excreted compounds and positively affected the nodulation and growth of soybeans.

The moment to induce the nodulation genes in Bradyrhizobium inoculants does not affect the nodulation neither soybean plants growth. 


\section{Acknowledgements}

The authors would like to express their gratitude to Rizobacter S.A and Fyteko S.A for funding part of the investigation. The authors also thank Damian Andres for his help in the experiments.

\section{References}

Bashan, Y., de-Bashan, L., Prabhu, S., \& Hernandez, J. (2014). Advances in plant growth-promoting bacterial inoculant technology: formulations and practical perspectives (1998-2013). Plant and Soil, 378, 1-33. https://doi.org/10.1007/ s11104-013-1956-X

Begum, A., Leibovitch, S., Migner, P., \& Zhang, F. (2001). Specific flavonoids induced nod gene expression and pre-activated nod genes of Rhizobium leguminosarum increased pea (Pisum sativum L.) and lentil (Lens culinaris L.) nodulation in controlled growth chamber environments. Journal of Experimental Botany, 52(360), 1537-1543. https://doi. org/10.1093/jexbot/52.360.1537

Brencic, A., \& Winans, S. (2005). Detection of and response to signals involved in host-microbe interactions by plant-associated bacteria. Microbiology and Molecular Biology Revew, 69(1), 155-194. https://doi.org/10.1128/MMBR.69.1.155194.2005

Demain, A. (1998). Induction of secondary metabolism. International Microbiology, 1(4), 259-264.

Djordjevic, M., Redmond, J., Batley, M., \& Rolfe, B. (1987). Clovers secrete specific phenolic compounds which either stimulate or repress nod gene expression in Rhizobium trifolii. The EMBO Journal, 6(5), 1173-1179. https://doi. org/10.1002/j.1460-2075.1987.tb02351.x

Gautam, K., Smith, D., \& Schwinghamer, S. (2016). The response of soybean to nod factors and a bacteriocin. Plant Signaling \& Behavior, 11(10), Article e1241934. https://doi.org/10.1080/15592324.2016.1241934

Hungria, M., Campo, R., Mendes, I., \& Graham, P. (2006). Contribution of biological nitrogen fixation to the N nutrition of grain crops in the tropics: the success of soybean (Glycine max L. Merr.) in South America. In R. P. Singh, N. Shankar, P. K. Jaiwal (Eds.), Nitrogen nutrition and sustainable plant productivity (pp. 43-93). Studium Press, LLC.

Hungria, M., \& Mendes, I. C. (2015). Nitrogen fixation with soybean: The perfect symbiosis? In F. J. de Bruijn (Ed.), Biological nitrogen fixation (pp. 1009-1024). John Wiley \& Sons, Inc. http://doi.org/10.1002/9781119053095.ch99

Jarecki, W. (2020). Reaction of soybean [Glycine max (L.) Merr.] to seed inoculation with Bradyrhizobium japonicum bacteria. Plant and Soil Environment, 66, 242-247. https://doi.org/10.17221/201/2020-PSE

Kosslak, R., Bookland, R., Barkei, J., Paaren, H., \& Appelbaum, E. (1987). Induction of Bradyrhizobium japonicum common nod genes by isoflavones isolated from Glycine max. Proceedings of the National Academy of Sciences, 82(21), 7428-7432. https://doi.org/10.1073/pnas.84.21.7428

Leggett, M., Diaz, M., Koivunen, M., Bowman, R., Pesek, R., Stevenson, C., \& Leister, T. (2017). Soybean Response to Inoculation with Bradyrhizobium japonicum in the United States and Argentina. Agronomy Journal, 109(3), 10311038. https://doi.org/10.2134/agronj2016.04.0214

Agron. Mesoam. 33(2): Artículo 46404, 2022

ISSN 2215-3608 doi:10.15517/am.v33i2.46404 
Marks, B., Megías, M., Nogueira, M., \& Hungria, M. (2013). Biotechnological potential of rhizobial metabolites to enhance the performance of Bradyrhizobium spp. and Azospirillum brasilense inoculants with soybean and maize. AMB Express, 3, Article 21. https://doi.org/10.1186/2191-0855-3-21

Mbengue, M., Hervé, C., \& Debellé, F. (2020). Nod factor signaling in symbiotic nodulation. Advances in Botanical Research, 94, 1-39. https://doi.org/10.1016/bs.abr.2019.10.002

Nápoles, M., Cabrera, J., Onderwater, R., Wattiez, R., Hernández, I., Martínez, L., \& Núñez, M. (2016). Signals produced by Rhizobium leguminosarum in the interaction with common bean (Phaseolus vulgaris L.). Cultivos Tropicales, 37(2), 37-44. https://doi.org/10.13140/RG.2.1.4466.8405

Naveed, M., Mchboob, I., \& Hussain, M. (2015). Perspectives of rhizobial inoculation for sustainable crop production. In N. K. Arora (Ed.), Plant microbes symbiosis: applied facets (pp. 209-239). Springer. https://doi.org/10.1007/978-981$10-4862-3$

Ramírez-Puebla, S., Hernández, M., Ruiz, G., Ormeño, E., Martinez, J., Servín, L., Amescua, A., Negrete, S., \& Martínez, E. (2019). Nodule bacteria from the cultured legume Phaseolus dumosus (belonging to the Phaseolus vulgaris crossinoculation group) with common tropici phenotypic characteristics and symbiovar but distinctive phylogenomic position and chromid. Systematic and Applied Microbiology, 42(3), 373-382. https://doi.org/10.1016/j.syapm.2018.12.007

Ramongolalaina, C., Teraishi, M., \& Okumoto, Y. (2018). QTLs underlying the genetic interrelationship between efficient compatibility of Bradyrhizobium strains with soybean and genistein secretion by soybean roots. PLoS ONE, 13(4), Article e0194671. https://doi.org/10.1371/journal.pone.0194671

Santos, M., Nogueira, M., \& Hungria, M. (2019). Microbial inoculants: reviewing the past, discussing the present and previewing an outstanding future for the use of beneficial bacteria in agriculture. AMB Express, 9, Article 205. https:// doi.org/10.1186/s13568-019-0932-0

Secchi, M., Torres, A., Moro, L., \& Ciampitti, I. (2019). Inoculation Timing Effect on Biological Nitrogen Fixation and Soybean Productivity. Kansas Agricultural Experiment Station Research Reports, 5(6), Article 10. https://doi. org/10.4148/2378-5977.7782

Vincent, J. M. (1970). A manual for the practical study of the root-nodule bacteria. Blackwell Scientific Publishers. 